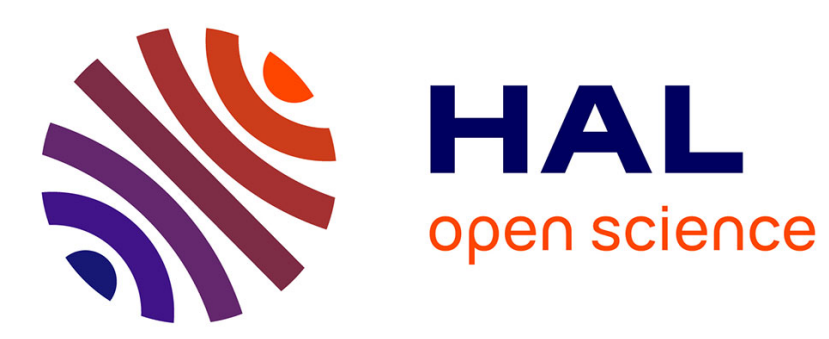

\title{
Plant essential oils and formamidines as insecticides/acaricides: what are the molecular targets?
}

Wolfgang Blenau, Eva Rademacher, Arnd Baumann

\section{To cite this version:}

Wolfgang Blenau, Eva Rademacher, Arnd Baumann. Plant essential oils and formamidines as insecticides/acaricides: what are the molecular targets?. Apidologie, 2012, 43 (3), pp.334-347. 10.1007/s13592-011-0108-7 . hal-01003531

\section{HAL Id: hal-01003531 https://hal.science/hal-01003531}

Submitted on 1 Jan 2012

HAL is a multi-disciplinary open access archive for the deposit and dissemination of scientific research documents, whether they are published or not. The documents may come from teaching and research institutions in France or abroad, or from public or private research centers.
L'archive ouverte pluridisciplinaire HAL, est destinée au dépôt et à la diffusion de documents scientifiques de niveau recherche, publiés ou non, émanant des établissements d'enseignement et de recherche français ou étrangers, des laboratoires publics ou privés. 


\title{
Plant essential oils and formamidines as insecticides/ acaricides: what are the molecular targets?
}

\author{
Wolfgang Blenau ${ }^{1}$, Eva Rademacher ${ }^{2}$, Arnd BaumanN $^{3}$ \\ ${ }^{1}$ Institut für Bienenkunde (Polytechnische Gesellschaft), Goethe-Universität Frankfurt am Main, \\ Karl-von-Frisch-Weg 2, 61440 Oberursel, Germany \\ ${ }^{2}$ Institute of Biology, Freie Universität Berlin, 14195 Berlin, Germany \\ ${ }^{3}$ Institute of Complex Systems-Cellular Biophysics-(ICS-4), Forschungszentrum Jülich, 52425 Jülich, Germany
}

Received 16 May 2011 - Revised 29 August 2011 - Accepted 21 October 2011

\begin{abstract}
The parasitic mite Varroa destructor is the main cause of the severe reduction in beekeeping during the last few decades. Therefore, efforts have been made to develop chemical treatments against the parasite. In the past, synthetic products were preferentially used to combat Varroa mites. Nowadays, mainly plant essential oils and organic acids are applied because they are safer and impose less unfavorable effects on the environment. Essential oils contain mixtures of mostly volatile and odorous terpenoid constituents. The molecular targets of these substances are tyramine and/or octopamine receptors that control and modulate vital functions ranging from metabolism to behavior. Disturbing the native function of these receptors in the mite results in deleterious effects in this parasite. This overview considers not only tyramine and octopamine receptors but also other potential targets of essential oils including ionotropic $\mathrm{GABA}_{\mathrm{A}}$ receptors, TRP type ion channels, and acetylcholinesterase.
\end{abstract}

\section{GABA / G protein-coupled receptor / octopamine / thymol / tyramine}

\section{PLANT ESSENTIAL OILS- AN INTRODUCTION}

The availability of environmentally safe and efficient chemicals against arthropod pests is an important aspect for veterinary and crop industries. At present, chemical compounds that rapidly deliver their insecticidal effect are preferentially used to achieve a timely reduction of pests and ectoparasites on their respective hosts. This condition is fulfilled by compounds that modify the activity of voltagegated and/or ligand-gated ion channels in the central nervous system (CNS) and by compounds that impair the activity of neuronal enzymes such

Corresponding author: W. Blenau,

Blenau@bio.uni-frankfurt.de

Manuscript editor: Bernd Grünewald as acetylcholinesterase (AChE) or that manipulate the overall metabolic status of the parasite (for a review, see Isman 2006). Substances such as synthetic pyrethroids inhibit voltagegated sodium channels that are important for the firing of neuronal action potentials. Phenylpyrazolines or polychloroalkanes (e.g., lindane) block the activity of $\mathrm{GABA}_{\mathrm{A}}$ channels, important members of the ligand-gated ion channel family involved in inhibitory signal generation in neurons. Organophosphates inhibit the enzymatic activity of AChE, an enzyme controlling the concentration of the excitatory neurotransmitter acetylcholine (ACh) in the synaptic cleft. Isoflavonoids such as rotenone poison mitochondria and thus cause the breakdown of cellular energy production. Metabotropic ( $\mathrm{G}$ protein-coupled) octopamine receptors are the target of formamidine pesticides such as amitraz which manipulate 
cellular signal transduction processes. Despite the efficient and wide use of these substances, they seem to harbor certain disadvantages. (1) Parasites can develop resistance to the chemicals, probably because the generation times of the arthropod pests are short. (2) Cross-reactivity of such substances might also be significant in beneficial insects such as the honeybee. In addition, these substances might cause undesired allergic or toxic effects in humans. For such reasons, there is a continual demand for compounds that, on the one hand, efficiently reduce parasites or pests and, on the other hand, are safe for the host, the environment, and non-target species, including man, that come into contact with such insecticides/acaricides. Over the years, plant essential oils have been considered as an attractive alternative that might fulfill these criteria.

Plant essential oils are complex mixtures of odorous substances obtained from botanical raw materials by water vapor extraction, dry distillation, or mechanical treatment without heating (Isman 2006; Vigan 2010). Because of their odorous character, plant essential oils are widely used as fragrances and flavorings in perfume and food industries. To identify and to further characterize the individual components of essential oils, either separation by gas chromatography or HPLC has to be performed. These analyses have identified monoterpenes, sesquiterpenes, and related aromatic compounds as the main constituents of plant essential oils. Terpenoids are derived from five-carbon isoprene units. Coupling of two isoprene units leads to ten-carbon structures known as monoterpenoids, whereas coupling of three isoprene units leads to sesquiterpenoids (Table I). Terpenoids can be linear (acyclic) or contain cyclic structures (Table I). Further biochemical modifications by endogenous plant enzymes can cause oxidation, rearrangement, or additional cyclization (Table I) that increases the variability of essential oil constituents (Chappell 1995; Holstein and Hohl 2004). At approximately $90 \%$, the mono- and sesquiterpenoids outnumber the other constituents of plant essential oils. Nevertheless, some aromatic compounds are worth mentioning (Table I).
Similar to their heterogeneous composition, plant essential oils display a broad spectrum of biological activity. They can be toxic for insects and microbes, but can also act as insect antifeedants and repellents (Anthony et al. 2005; Isman 2006; Nerio et al. 2010; Vigan 2010). The toxic effect of essential oils is most likely mediated by neurological mechanisms. Indeed, plant essential oils have been suggested to exert their bioactivity by interacting with various molecular targets including tyramine and octopamine receptors (Enan 2001, 2005a, b; Price and Berry 2006), ionotropic GABA receptors (Priestley et al. 2003; Tong and Coats 2010), and AChE (Grundy and Still 1985; Ryan and Byrne 1988; Keane and Ryan 1999). As previously mentioned, octopamine receptors have also been identified as a target site of the formamidine class of insecticides (Evans and Gee 1980; Gole et al. 1983; Downer et al. 1985; Dudai et al. 1987; Chen et al. 2007).

In mammalian tissues, $p$-tyramine, $\beta$ phenylethylamine, tryptamine, and octopamine are present at very low (nanomolar) concentrations and are therefore referred to as "trace amines." Trace amine-associated receptors (TAARs) have recently been discovered in mammals (for a review, see Zucchi et al. 2006). It is worth emphasizing, however, that thus far, only two members of the TAAR family have been shown to be responsive to trace amines. In addition, mammalian TAARs are not closely related to arthropod tyramine and octopamine receptors. Thus, it appears that in mammals, TAARs evolved independently from the arthropod tyramine and octopamine receptors and acquired the ability to interact with different amines, including the decarboxylated thyroid hormone derivatives known as thyronamines, several volatile amines, and possibly other as yet unidentified endogenous compounds (for a review, see Zucchi et al. 2006). Therefore, arthropod tyramine and octopamine receptors might emerge as promising targets for insecticides/acaricides (e.g., plant essential oil components) with no or low toxicity in vertebrates. 
Table I. Naturally occurring essential oil components and synthetic substances mentioned in the text.

\begin{tabular}{lll}
\hline Compound & $\begin{array}{l}\text { Molecular } \\
\text { formula }\end{array}$ & Substance class \\
\hline $\begin{array}{l}\text { Linalool [licareol }=(R)-(-)- \\
\text { linalool; coriandrol=(S)- } \\
(+)-\text { linalool] }\end{array}$ & $\mathrm{C}_{10} \mathrm{H}_{18} \mathrm{O}$ & $\begin{array}{l}\text { Monoterpenoid alcohol, } \\
\text { linear }\end{array}$ \\
& &
\end{tabular}

Citral [geranial $=$ citral A;
neral $=$ citral $\mathrm{B}$ ] $\quad \mathrm{C}_{10} \mathrm{H}_{16} \mathrm{O} \quad \begin{aligned} & \text { Monoterpenoid aldehyde, } \\ & \text { linear }\end{aligned}$

$\alpha$-Terpineol $\quad \begin{gathered}\mathrm{C}_{10} \mathrm{H}_{20} \mathrm{O} \quad \begin{array}{c}\text { Monoterpenoid alcohol, } \\ \text { monocyclic, unsaturated } \\ \text { Monoterpenoid alcohol, } \\ \text { monocyclic, unsaturated }\end{array} \\ \mathrm{C}_{10} \mathrm{H}_{18} \mathrm{O} \quad \begin{array}{c}\text { monol } \\ \text { mons }\end{array}\end{gathered}$

Carveol

Pulegone

$R$-(-)-Carvone, $S-(+)-$ carvone

$\alpha$-Terpinene, $\gamma$-terpinene

p-Cymene

Carvacrol

Thymol

Anethole (para-

methoxyphenylpropene,
$\mathrm{C}_{10} \mathrm{H}_{14} \mathrm{O}$

Monoterpenoid phenolic derivative of cymene

$\mathrm{C}_{10} \mathrm{H}_{16} \mathrm{O} \quad$ Monoterpenoid alcohol, monocyclic, unsaturated

$\mathrm{C}_{10} \mathrm{H}_{16} \mathrm{O} \quad$ Monoterpenoid ketone, monocyclic

$\mathrm{C}_{10} \mathrm{H}_{14} \mathrm{O} \quad \begin{gathered}\text { Monoterpenoid ketone, } \\ \text { monocyclic, unsaturate }\end{gathered}$

$\mathrm{C}_{10} \mathrm{H}_{16}$

Monoterpenoid, monocyclic, unsaturated

$\mathrm{C}_{10} \mathrm{H}_{14}$

Monoterpenoid, monocyclic, aromatic

$\mathrm{C}_{10} \mathrm{H}_{14} \mathrm{O} \quad$ Monoterpenoid phenol
Sources (examples)

Coriandrum sativum (coriander)

Ocimum basilicum (basil)

Citrus $\times$ sinensis (sweet orange)

Backhousia citriodora

(lemon myrtle)

Cymbopogon spp.

(lemongrass)

Leptospermum liversidgei

(lemon tea tree)

Mentha $\times$ piperita

(peppermint)

Melaleuca leucadendra

(cajuput oil)

Pinus spp. (pine oil)

Citrus $\times$ aurantium (petitgrain oil)

cis-(-)-Carveol:

Mentha spicata (spearmint)

Nepeta cataria (catnip)

Mentha $\times$ piperita

(peppermint)

Mentha pulegium

(pennyroyal)

$S$-(+)-carvone

Carum carvi (caraway)

Anethum graveolens (dill)

$R$-(-)-carvone

Mentha spicata (spearmint)

Melaleuca alternifolia

(tea tree oil)

Citrus $\times$ limon (bergamot oil)

Cuminum cyminum (cumin)

Chenopodium ambrosioides

(epazote)

Peumus boldus (boldo)

Origanum vulgare (oregano)

Thymus spp. (thyme)

Lepidium spp. (pepperwort)

Thymus spp. (thyme)

Trachyspermum copticum (ajwain)

Origanum vulgare (oregano)

Pimpinella anisum (anise)

Foeniculum vulgare (fennel) 
Table I continued.

\begin{tabular}{|c|c|c|c|}
\hline Compound & $\begin{array}{l}\text { Molecular } \\
\text { formula }\end{array}$ & Substance class & Sources (examples) \\
\hline $\begin{array}{l}p \text {-propenylanisole, } \\
\text { isoestragole) }\end{array}$ & & & $\begin{array}{l}\text { Syzygium anisatum } \\
\text { (anise myrtle) }\end{array}$ \\
\hline \multirow[t]{3}{*}{ Eugenol } & \multirow[t]{3}{*}{$\mathrm{C}_{10} \mathrm{H}_{12} \mathrm{O}_{2}$} & \multirow[t]{3}{*}{$\begin{array}{l}\text { Monoterpenoid, methoxy-phenol, } \\
\text { unsaturated }\end{array}$} & $\begin{array}{l}\text { Syzygium aromaticum } \\
\text { (clove oil) }\end{array}$ \\
\hline & & & Pimenta dioica (allspice) \\
\hline & & & Myristica fragrans (nutmeg) \\
\hline \multirow[t]{6}{*}{ (+)-Camphor, (-)-camphor } & \multirow[t]{6}{*}{$\mathrm{C}_{10} \mathrm{H}_{16} \mathrm{O}$} & \multirow{6}{*}{$\begin{array}{l}\text { Monoterpenoid ketone, } \\
\text { bicyclic }\end{array}$} & $(+)$-Camphor \\
\hline & & & $\begin{array}{l}\text { Cinnamomum camphora } \\
\text { (camphor laurel) }\end{array}$ \\
\hline & & & $\begin{array}{l}\text { Rosmarinus officinalis } \\
\text { (rosemary) }\end{array}$ \\
\hline & & & (-)-Camphor \\
\hline & & & $\begin{array}{l}\text { Tanacetum parthenium } \\
\text { (feverfew) }\end{array}$ \\
\hline & & & $\begin{array}{l}\text { Matricaria recutita } \\
\text { (German chamomile) }\end{array}$ \\
\hline \multirow[t]{2}{*}{$\alpha$-Pinene; $\beta$-pinene } & \multirow[t]{2}{*}{$\mathrm{C}_{10} \mathrm{H}_{16}$} & \multirow{2}{*}{$\begin{array}{l}\text { Monoterpenoid, bicyclic, } \\
\text { unsaturated }\end{array}$} & Pinus spp. (pine resin) \\
\hline & & & $\begin{array}{l}\text { Rosmarinus officinalis } \\
\text { (rosemary) }\end{array}$ \\
\hline \multirow[t]{3}{*}{$(+)$-Borneol } & \multirow[t]{3}{*}{$\mathrm{C}_{10} \mathrm{H}_{18} \mathrm{O}$} & \multirow[t]{3}{*}{$\begin{array}{l}\text { Monoterpenoid ketone, } \\
\text { bicyclic }\end{array}$} & $\begin{array}{l}\text { Cinnamomum camphora } \\
\text { (camphor oil) }\end{array}$ \\
\hline & & & $\begin{array}{l}\text { Coriandrum sativum } \\
\text { (coriander) }\end{array}$ \\
\hline & & & Tanacetum vulgare (tansy) \\
\hline \multirow[t]{3}{*}{ Bornyl acetate } & \multirow[t]{3}{*}{$\mathrm{C}_{12} \mathrm{H}_{20} \mathrm{O}_{2}$} & \multirow[t]{3}{*}{ Acetic acid ester of borneol } & Abies spp. (fir) \\
\hline & & & Pinus spp. (pine) \\
\hline & & & Picea spp. (spruce) \\
\hline \multirow[t]{3}{*}{$\begin{array}{l}\text { Eucalyptol (1,8-cineol, 1, } \\
\text { 8-cineole, cineol, cineole) }\end{array}$} & \multirow[t]{3}{*}{$\mathrm{C}_{10} \mathrm{H}_{18} \mathrm{O}$} & \multirow[t]{3}{*}{$\begin{array}{l}\text { Monoterpenoid, } \\
\text { oxa-bicyclic }\end{array}$} & $\begin{array}{l}\text { Eucalyptus spp. } \\
\text { (eucalyptus oil) }\end{array}$ \\
\hline & & & $\begin{array}{l}\text { Cinnamomum camphora } \\
\text { (camphor laurel) }\end{array}$ \\
\hline & & & Laurus nobilis (bay leaf) \\
\hline \multirow[t]{3}{*}{ Farnesol } & \multirow[t]{3}{*}{$\mathrm{C}_{15} \mathrm{H}_{26} \mathrm{O}$} & \multirow[t]{3}{*}{ Sesquiterpene, linear } & $\begin{array}{l}\text { Cymbopogon spp. } \\
\text { (lemongrass, citronella oil) }\end{array}$ \\
\hline & & & $\begin{array}{l}\text { Citrus } \times \text { aurantium (bitter } \\
\text { orange, neroli oil) }\end{array}$ \\
\hline & & & $\begin{array}{l}\text { Polianthes tuberosa } \\
\text { (tuberose) }\end{array}$ \\
\hline \multirow[t]{3}{*}{ Cinnamic alcohol } & \multirow[t]{3}{*}{$\mathrm{C}_{9} \mathrm{H}_{10} \mathrm{O}$} & \multirow[t]{3}{*}{$\begin{array}{l}\text { Aromatic, unsaturated } \\
\text { alcohol }\end{array}$} & $\begin{array}{l}\text { Liquidambar orientalis } \\
\text { (storax) }\end{array}$ \\
\hline & & & $\begin{array}{l}\text { Myroxylon balsamum } \\
\text { (balsam Peru) }\end{array}$ \\
\hline & & & $\begin{array}{l}\text { Cinnamomum spp. } \\
\text { (cinnamon) }\end{array}$ \\
\hline Cinnamaldehyde & $\mathrm{C}_{9} \mathrm{H}_{8} \mathrm{O}$ & Aromatic, unsaturated aldehyde & $\begin{array}{l}\text { Cinnamomum spp. } \\
\text { (cinnamon) }\end{array}$ \\
\hline Capsaicin & $\mathrm{C}_{18} \mathrm{H}_{27} \mathrm{NO}_{3}$ & Capsaicinoid, 8-methyl- & Capsicum spp. (chili pepper) \\
\hline
\end{tabular}


Table I continued.

\begin{tabular}{|c|c|c|c|}
\hline Compound & $\begin{array}{l}\text { Molecular } \\
\text { formula }\end{array}$ & Substance class & Sources (examples) \\
\hline & & $\begin{array}{l}N \text {-vanilyl-6-nonenamide, } \\
\text { aromatic }\end{array}$ & \\
\hline Chlordimeform & $\mathrm{C}_{10} \mathrm{H}_{13} \mathrm{ClN}_{2}$ & Amidine, organochloride & Synthetic \\
\hline Demethylchlordimeform & $\mathrm{C}_{9} \mathrm{H}_{11} \mathrm{ClN}_{2}$ & $\begin{array}{l}\text { Amidine, organochloride, } \\
\text { aromatic }\end{array}$ & Synthetic \\
\hline Amitraz & $\mathrm{C}_{19} \mathrm{H}_{23} \mathrm{~N}_{3}$ & $\begin{array}{l}\text { Amidine, triazapentadiene, } \\
\text { aromatic }\end{array}$ & Synthetic \\
\hline
\end{tabular}

For each substance, the molecular formula, characteristic structural properties, and a selection of natural sources synthesizing the compound are given

\section{USE OF PLANT ESSENTIAL OILS FOR VARROA TREATMENT OF HONEYBEE COLONIES}

The honeybee, Apis mellifera, pollinates about $80 \%$ of crop and wild plants. This makes it the fourth most important farm animal in Germany (after cattle, pigs, and poultry). Hence, it is alarming that the honeybee stocking density has rapidly declined over the last few decades. One reason for this dramatic reduction in beekeeping is the parasitic mite Varroa destructor, which was introduced into Germany in the 1970s. $V$. destructor can only reproduce in a honeybee colony, precisely in sealed brood cells. It attaches to the body of the larva, pupa, or adult bee and weakens its host by sucking hemolymph (for reviews, see Rademacher 1990; Sammataro et al. 2000; Rosenkranz et al. 2010). The mite acts as a vector and spreads RNA viruses such as deformed wing virus to the bee (for reviews, see Genersch and Aubert 2010; Le Conte et al. 2010). A significant mite infestation will lead to the death of the honeybee colony, usually during the summer or winter months. $V$. destructor is the parasite with the most pronounced economic impact on the beekeeping industry. It is a major contributing factor to colony collapse disorder (CCD) and to non-CCD winter losses, which constitute severe problems in beekeeping worldwide (Vanengelsdorp et al. 2009; GuzmanNovoa et al. 2010; for a review, see Le Conte et al. 2010). Honeybees in CCD colonies are characterized by higher pathogen loads and are co-infected with a greater number of pathogens compared with control populations, suggesting an interaction between pathogens and other stress factors in CCD and a possible legacy effect of Varroa parasitism (Vanengelsdorp et al. 2009).

Numerous efforts have been made to develop chemical treatments against $V$. destructor (Mutinelli and Rademacher 2003; Rosenkranz et al. 2010). Nowadays, products based on organic acids (e.g., formic acid and oxalic acid; Rademacher and Imdorf 2004; Rademacher and Harz 2006; Calderone 2010), essential oils (e.g., thymol; Imdorf et al. 1995, 1999; Rademacher and Radtke 2001; Floris et al. 2004), pyrethroids (e.g., fluvalinate and flumethrin), organophosphates (e.g., coumaphos; Milani and Lob 1998), and formamidines (e.g., amitraz; Floris et al. 2001) are used to treat infected colonies. Essential oils (and formamidines) most probably exert their therapeutic effects by binding to tyramine and/or octopamine receptors. Amongst others, thymol (e.g., Apiguard and Thymovar) and combinations of thymol and other essential oils such as eucalyptol, camphor, and menthol (e.g., Api Life VAR) are also used for Varroa treatment (Imdorf et al. 1999) and have been approved as veterinary drugs in many European countries. Calderone and Spivak (1995) found that a blend of natural products similar to Api Life VAR provided more than $98.5 \%$ control of $V$. destructor. In a recent study, Ghasemi et al. (2011) determined the fumigant toxicity of essential oils taken from Thymus kotschyanus, 
Ferula assa-foetida, and Eucalyptus camaldulensis against $V$. destructor and A. mellifera. Interestingly, whereas the essential oil of $T$. kotschyanus is the most potent fumigant for $V$. destructor, it has the lowest insecticidal activity against A. mellifera (Ghasemi et al. 2011). Noteworthy is that menthol is used to treat hives infested with the tracheal mite, Acarapis woodi, which is an internal parasite of honeybees. On the one hand, essential oils have not yet led to resistant mite populations, but on the other hand, they are not consistently highly active in reducing mite populations in all situations (Le Conte et al. 2010). In addition, treatments using thymol as their active substance are suspected to have adverse effects on honeybee colonies. Interestingly, honeybee responses to Apiguard treatment change with honeybee age (Mondet et al. 2011). While 2-day-old bees respond neutrally to Apiguard, foragers appear to be repelled by Apiguard, but can become habituated to the treatment (Mondet et al. 2011).

\section{OCTOPAMINE AND TYRAMINE RECEPTORS AS MOLECULAR TARGETS OF PLANT ESSENTIAL OILS AND FORMAMIDINE PESTICIDES}

Biogenic amines are small organic compounds that act as neurotransmitters, neuromodulators, and/or neurohormones in vertebrates and in invertebrates. They represent an important group of messenger substances and mediate their diverse effects by binding to membrane receptors that belong to the large gene family coding for $G$ protein-coupled receptors. In arthropods, the group of biogenic amine messengers consists of five members: dopamine, tyramine, octopamine, serotonin, and histamine. Receptor activation leads to changes in the concentration of intracellular second messengers (e.g., cAMP or $\left.\mathrm{InsP}_{3} / \mathrm{Ca}^{2+}\right)$. For each amine, multiple receptor subtypes exist that couple to various intracellular signaling pathways in a receptorspecific manner (for reviews, see Blenau and Baumann 2001, 2003; Evans and Maqueira 2005; Scheiner et al. 2006; Hauser et al. 2006;
Verlinden et al. 2010a; Blenau and Thamm 2011). In the honeybee, three dopamine receptors (AmDOP1: Blenau et al. 1998; Mustard et al. 2003; AmDOP2: Humphries et al. 2003; Mustard et al. 2003; AmDOP3: Beggs et al. 2005), one tyramine receptor (AmTYR1: Blenau et al. 2000; Mustard et al. 2005), one octopamine receptor (AmOA1: Grohmann et al. 2003), and two serotonin receptors (Am5-HT $1 \mathrm{~A}$ : Thamm et al. 2010; Am5-HT 7 : Schlenstedt et al. 2006) have been characterized. Aminergic receptors have also been characterized in locusts (Locusta migratoria: Vanden Broeck et al. 1995; Schistocerca gregaria: Verlinden et al. 2010b) and the American cockroach (Periplaneta americana; Bischof and Enan 2004; Rotte et al. 2009; Troppmann et al. 2010). These hemimetabolous insects not only are pest insects but also serve as model organisms for basic research in neurobiology and pharmacology. The successful completion of various insect genome sequencing projects has led to the annotation of additional receptor genes by bioinformatics (Drosophila melanogaster: Brody and Cravchik 2000; Anopheles gambiae: Hill et al. 2002; A. mellifera: Hauser et al. 2006; Tribolium castaneum: Hauser et al. 2008). Unfortunately, knowledge of aminergic receptors in mites remains limited. So far, only one tyramine receptor (Baxter and Barker 1999) and one serotonin receptor (Chen et al. 2004) of the cattle tick, Boophilus microplus, and two dopamine receptors (Meyer et al. 2011) of the blacklegged tick, Ixodes scapularis, have been molecularly identified. To date, no molecular data on aminergic receptors are available for $V$. destructor.

The neurotoxic activity of essential oils and/ or their purified constituents (eugenol, $\alpha$ terpineol, cinnamic alcohol) against various insect species is probably attributable to binding to tyramine and octopamine receptors (Enan 2001). Octopamine and essential oil constituents $(10 \mathrm{nM})$ have been found to cause a significant increase in intracellular cAMP concentration $\left([\mathrm{cAMP}]_{\mathrm{i}}\right)$ in the cotton bollworm, Helicoverpa armigera (Kostyukovsky et al. 2002). The octopamine receptor antagonist phentolamine effectively inhibits the increase in $[\mathrm{cAMP}]_{\mathrm{i}}$ 
induced by essential oil treatment. These results support the hypothesis that native octopamine receptors are targets of essential oil constituents (Kostyukovsky et al. 2002).

This hypothesis has subsequently been supported by evidence from cloned and heterologously expressed receptors. Enan (2005a) has shown that the toxicity rank order of $p$-cymene, thymol, carvacrol, $\alpha$-terpineol, and $R-(-)$-carvone for $D$. melanogaster correlates with their binding affinity to a heterologously expressed tyramine receptor (TyrR). The main route by which this receptor acts causes a reduction in $[\mathrm{cAMP}]_{\mathrm{i}}$. When heterologously expressed in D. melanogaster S2 cells, the activation of the tyramine receptor also causes an increase in the intracellular $\mathrm{Ca}^{2+}$ concentration (Enan 2005a). Interestingly, two compounds, i.e., thymol and carvacrol, are not toxic for a tyramine receptor mutant $\left(\mathrm{TyrR}^{\mathrm{neo30}}\right.$; Enan 2005a). In this mutant, the insertion of a $\mathrm{P}$ element abolishes the expression of a functional receptor protein (Cooley et al. 1988). Together, these results suggest that thymol and carvacrol mediate their toxic effects via tyramine receptors. Notably, the specific binding of essential oil components (eugenol, cinnamic alcohol, transanethole) to an octopamine receptor from $D$. melanogaster and its ortholog from the cockroach, $P$. americana $\left(\mathrm{Pa} \mathrm{oa}_{1}\right)$, has also been reported (Enan 2005b).

As early as the middle of the 1980s, the formamidines demethylchlordimeform (DMCD), BTS-27271, and amitraz were shown to mimic the action of octopamine in elevating adenylyl cyclase activity in the nervous tissue of $P$. americana (Gole et al. 1983; Downer et al. 1985). In D. melanogaster, however, DMCD and chlordimeform inhibit octopamine-stimulated adenylyl cyclase activity, whereas amitraz activates the enzyme (Dudai et al. 1987). Both octopamine and chlordimeform potentiate contractions of the locust slow extensor tibiae muscle (Evans and Gee 1980). Furthermore, chlordimeform and DMCD elicit light production in the firefly (Photinus pyralis) lantern, which is controlled by octopaminergic neurons (Hollingworth and Murdock 1980). All these results argue in favor of formamidines interacting with octopamine receptors. Interestingly, some formamidines show an even higher affinity for octopamine receptors in the CNS of insects than the natural ligand octopamine itself (Hiripi et al. 1994; Roeder 1995). The interaction of formamidines with octopamine receptors results in hyperexcitability, abnormal behavior, paralysis, and death in insects (Dudai et al. 1987), and also in the detachment and mortality of parasitic acarines (Stone et al. 1974). Chlordimeform $\mathrm{HCl}$ (K-79) has been tested for the treatment of varroosis and has been shown to be highly toxic for $V$. destructor, but only slightly toxic for bees (Rademacher 1981; Wachendörfer et al. 1981). In veterinary medicine, amitraz is used to control ectoparasitic mites and insects (Hollingworth 1976). In some European countries, amitraz is applied in the form of special plastic strips that slowly release the agent to control $V$. destructor (Floris et al. 2001). In other countries, amitraz is applied as an aerosol or a spray. In this form, amitraz is highly unstable and becomes rapidly degraded into various partly poisonous metabolites. For this reason, the compound is not licensed for the treatment of honeybee colonies in Germany. Another side effect of amitraz treatment is that mites can become resistant to the chemical (Elzen et al. 2000; for a review, see Jonsson and Hope 2007). Notably, amino acid substitutions have been identified in the receptor sequence coding for a putative octopamine/ tyramine receptor in the cattle tick, B. microplus, in two amitraz-resistant strains (Chen et al. 2007). These substitutions are absent in all amitrazsusceptible strains. The discovery of such mutations in amitraz-resistant ticks provides evidence for these amino acid residues being part of the pesticide-binding site of the wild-type receptor.

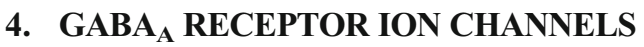 AS MOLECULAR TARGETS OF PLANT ESSENTIAL OILS}

Fast neuronal signaling by the neurotransmitter $\gamma$-aminobutyric acid (GABA) is mediated by ionotropic $\mathrm{GABA}_{\mathrm{A}}$ receptors. These are pentameric complexes with an integral GABA-gated 
anion channel (for a review, see Buckingham et al. 2005). Insect $\mathrm{GABA}_{\mathrm{A}}$ receptors are targets for several insecticides, such as dieldrin, lindane, BIDN, and fipronil, all of which act as antagonists (for a review, see Bloomquist 1996). The monoterpenoid thymol, applied in concentrations between 1 and $100 \mu \mathrm{M}$, potentiates the action of GABA at recombinant human $\mathrm{GABA}_{\mathrm{A}}$ receptors with various subunit compositions and also at an insect (D. melanogaster) ionotropic GABA receptor (Priestley et al. 2003). The enhanced response to GABA is likely to be the result of a positive allosteric action of thymol (Priestley et al. 2003). The direct agonistic action of thymol has been observed at both mammalian and insect recombinant receptors between 100 and $500 \mu \mathrm{M}$ (Priestley et al. 2003). Thymol does not appear to compete with other GABAergic ligands. Thus, the effect of thymol is possibly mediated by a binding site that is not yet characterized and that could represent a new avenue in insecticide research (Priestley et al. 2003). Recently, Tong and Coats (2010) evaluated the pharmacological action of five monoterpenoids ( $\alpha$-terpineol, carvacrol, linalool, pulegone, and thymol) on native insect $\mathrm{GABA}_{\mathrm{A}}$ receptors from houseflies and American cockroaches using radiotracer methods. The binding of $\left[{ }^{3} \mathrm{H}\right] t$-butylbicycloorthobenzoate $\left(\left[{ }^{3} \mathrm{H}\right]-\mathrm{TBOB}\right)$ to membrane preparations of housefly heads was enhanced by carvacrol, pulegone, and thymol with $\mathrm{EC}_{50}$ values of $48 \mu \mathrm{M}, 432 \mu \mathrm{M}$, and $6 \mathrm{mM}$, respectively. Moreover, these three monoterpenoids at concentrations of $500 \mu \mathrm{M}$ and $1 \mathrm{mM}$ also significantly increased the GABA-induced ${ }^{36} \mathrm{Cl}^{-}$ uptake in membrane microsacs prepared from American cockroach ventral nerve cords. The authors concluded that carvacrol, pulegone, and thymol are all positive allosteric modulators at insect $\mathrm{GABA}_{\mathrm{A}}$ receptors (Tong and Coats 2010). In contrast, $\alpha$-terpineol and linalool showed little or no effect on both $\left[{ }^{3} \mathrm{H}\right]$-TBOB binding and ${ }^{36} \mathrm{Cl}^{-}$uptake assays (Tong and Coats 2010). In the blowfly, Phaenicia sericata, thymol reduced the frequency of flight muscle impulses and, consequently, inhibited wing beat frequency (Waliwitiya et al. 2010). The similarity of thymol and GABA actions suggests that thymol acts centrally by mimicking or facilitating the action of GABA (Waliwitiya et al. 2010).

A closer look at the above data reveals that micromolar concentrations are needed for all described effects of essentials oil components on $\mathrm{GABA}_{\mathrm{A}}$ receptor channels. This makes the hypothesis of $\mathrm{GABA}_{\mathrm{A}}$ receptors being responsible for the insecticidal activity of essential oils rather questionable.

\section{ION CHANNELS OF THE TRP FAMILY ARE INHIBITED/ ACTIVATED BY MONOTERPENOIDS}

Transient receptor potential (TRP) channels are essential components of signaling cascades in sensory cells specialized to detect painful stimuli, such as heat, cold, and pressure, and chemicals, such as acids or irritants. The seven subfamilies of TRP channels are clustered into two groups, with five members in group 1, i.e., TRPC (" $\mathrm{C}$ " for canonical), TRPV ("V" for vanilloid), TRPM ("M" for melastatin), TRPN, and TRPA. Two subfamilies constitute group 2, i.e., TRPP ("P" for polycystic) and TRPML ("ML" for mucolipin; for a review, see Venkatachalam and Montell 2007). The D. melanogaster TRPC channels, TRP and TRP-like (TRPL), are the founding members of the TRP superfamily. In D. melanogaster, TRP channels are specifically expressed in photoreceptor cells of the complex eye. Upon illumination, TRP channels are activated and cause the depolarization of the photoreceptor cell (for a review, see Raghu and Hardie 2009). The thermoTRPs, which include TRPV1-4, TRPM8, and TRPA1, constitute a subgroup of TRP channels that are activated by either hot or cold temperatures and also by natural compounds evoking "hot" (e.g., capsaicin) or "cold" (e.g., menthol) sensations, respectively (Macpherson et al. 2006; Xu et al. 2006; Vogt-Eisele et al. 2007; Lee et al. 2008).

Recently, Parnas et al. (2009) have demonstrated, by patch clamp whole cell recording from D. melanogaster S2 and D. melanogaster photoreceptor cells, that carvacrol $(500 \mu \mathrm{M})$, a known activator of the mammalian ther- 
moTRPs, TRPV3, and TRPA1, acts as an inhibitor of native TRP channels and of both native and heterologously expressed TRPL channels. Furthermore, thymol (1 mM), eugenol ( $3 \mathrm{mM})$, cinnamaldehyde $\left(\mathrm{IC}_{50}=1.6 \mathrm{mM}\right)$, menthol $\left(\mathrm{IC}_{50}=1.81 \mathrm{mM}\right)$, and carveol $\left(\mathrm{IC}_{50}=\right.$ $4.22 \mathrm{mM}$ ), which are activators of mammalian TRPV3, have also been found to inhibit the TRPL channel (Parnas et al. 2009). Interestingly, high concentrations of borneol $(5 \mathrm{mM})$ and camphor $(10 \mathrm{mM})$ activate the TRPL channel (Parnas et al. 2009). Whether the interaction of millimolar concentrations of plant essential oil components with ion channels of the TRP family correlates with their insecticidal/acaricidal properties needs further validation.

\section{INHIBITION OF ACETYLCHOLINESTERASE ACTIVITY BY MONOTERPENOIDS}

ACh is an important neurotransmitter in both the CNS and the peripheral nervous system of many organisms including arthropods. Once released, ACh has a short half-life because of the enzymatic activity of AChE, which hydrolyzes ACh to choline and acetate in the synaptic cleft. Thus, AChE inhibitors (e.g., organophosphates or carbamates such as physostigmine or neostigmine) can be used to increase the ACh concentration and to prolong its functional activity in the nervous system.

As early as 1985, however, Grundy and Still demonstrated that $(+)$-pulegone and related monoterpenoids inhibit both housefly and Madagascar roach (Gromphadorhina portentosa) AChE activity in vitro (Grundy and Still 1985). In a pioneering study on "plant-insect co-evolution and inhibition of acetylcholinesterase," monoterpenoids (i.e., eucalyptol, pulegone, linalool, citral, and (-)-bornyl acetate) were convincingly shown to inhibit AChE purified from the electric eel (Ryan and Byrne 1988). Similar to the results obtained for AChE from electric eel, the five monoterpenoids were found to be reversible competitive inhibitors of AChE purified from the brain of the waxmoth, Galleria mellonella (Keane and Ryan 1999).
The $K_{\mathrm{i}}$ values were: eucalyptol, $220 \mathrm{nM}$; pulegone, $32 \mu \mathrm{M}$; linalool, $240 \mu \mathrm{M}$; citral, $330 \mu \mathrm{M}$; (-)-bornyl acetate, $510 \mu \mathrm{M}$ (Keane and Ryan 1999). In addition, eucalyptol inhibits AChE activity in homogenates obtained from head louse with an $\mathrm{IC}_{50}$ of $77 \mathrm{mM}$ (Picollo et al. 2008). Leaf oils of E. camaldulensis and their constituents (e.g., eucalyptol, $p$-cymene, $\gamma$ terpinene) act as both fumigants and contact toxicants on termites, Coptotermes formosanus; this is most likely attributable to the inhibition of AChE activity (Siramon et al. 2009). $\beta$-Pinene $\left(K_{\mathrm{i}}=2.8 \mu \mathrm{M}\right)$ and menthol $\left(K_{\mathrm{i}}=48 \mu \mathrm{M}\right)$ are potent inhibitors of $\mathrm{AChE}$ from the rice weevil, Sitophilus oryzae, one of the main stored grain pests (Lee et al. 2001).

In conclusion, many terpenoids might act as AChE inhibitors, both in arthropods and in vertebrates (for a review, see Houghton et al. 2006), but at relatively high concentrations (see above; Kostyukovsky et al. 2002). Whether terpenoid toxicity is correlated with their ability to inhibit AChE activity needs further experimental evidence (Grundy and Still 1985; Lee et al. 2001).

\section{PLANT ESSENTIAL OILS AS INSECTICIDES/ACARICIDES- AN OUTLOOK}

Monoterpenoids and related aromatic compounds show a broad spectrum of actions in insects and mites, with tyramine and octopamine receptors being likely candidates for their molecular targets. In addition to affecting tyramine and/or octopamine receptors, some of the compounds show other modes of action. Thymol, for example, affects insect $\mathrm{GABA}_{\mathrm{A}}$ receptors (Priestley et al. 2003; Tong and Coats 2010) and D. melanogaster TRP and TRPL channels (Parnas et al. 2009).

So far, nothing is known about the aminergic receptors of $V$. destructor. This is surprising as substances belonging to two different chemical classes used for Varroa treatment exert their actions by binding to aminergic receptors. To understand the mode of action of essential oils and formamidines, the molecular signature(s) of 
tyramine and octopamine receptors expressed in $V$. destructor and other arthropod pests therefore need to be unraveled.

A major concern about compounds currently used for Varroa treatment is their (potential) toxicity for the bees. Hoppe (1990) examined 55 essential oils for mite and bee toxicity. After 72 h, 24 essential oils produced a mite mortality of more than $90 \%$. However, of these 24 oils, only nine resulted in bee mortality below $10 \%$ ! Consequently, when applying these compounds, special care has to be taken to use concentrations that are toxic for mites but that have no or only minor toxicity for bees. For example, concentrations of 5-15 $\mu \mathrm{g}$ thymol, $50-150 \mu \mathrm{g}$ camphor, or 20-60 $\mu \mathrm{g}$ menthol per liter of air killed nearly $100 \%$ of the mites without a noticeable loss of bees (Imdorf et al. 1999).

By likewise testing compounds that are active on tyramine and/or octopamine receptors of $V$. destructor and orthologous receptors of the bee, dose-response curves for receptors expressed in both species can be determined. In this way, compounds or combinations of compounds and the relevant concentrations that are highly toxic for mites but non-toxic for bees can be identified with justifiable costs.

During the last few years, protein structurebased drug design has become a valuable and integral part of the discovery of active agents. This strategy is also applicable for arthropod tyramine and octopamine receptors once their primary structure is known. Huang et al. (2007) performed homology modeling for an octopamine receptor of the silkworm, Bombyx mori (BmOAR1). Subsequently, the octopamine molecule was manually docked into the potential binding site of the BmOAR1 receptor according to mutagenesis data (Huang et al. 2007). In order to understand the interaction of the cockroach $\mathrm{Pa} \mathrm{oa}_{1}$ receptor (Bischof and Enan 2004) with its ligands, a three-dimensional model of $\mathrm{Pa} \mathrm{oa}_{1}$ was computed and then its agonist binding site was identified, followed by docking studies (Hirashima and Huang 2008). These molecular docking studies have shown that ligands with certain substituents possibly act as potential $\mathrm{Pa} \mathrm{oa}_{1}$ agonists (Hirashima and
Huang 2008). Similar receptor models should be established for the tyramine and octopamine receptors of arthropod parasites (including $V$. destructor) and pests. These models can then be used to design new pharmaceutical leads for use as potent and relatively specific agonists/ antagonists for tyramine and octopamine receptors, thereby acting as potential pest control agents.

\section{ACKNOWLEDGMENTS}

We wish to thank Prof. B. Grünewald (Oberursel) for the invitation to submit this review article. The work of the authors was supported by the German Science Foundation (BL 469/7).

Huiles essentielles de plantes et formamidines, comme insecticides/acaricides: quelles sont leurs cibles moléculaires?

GABA / récepteur couplé à une protéine G / octopamine / thymol / tyramine

Ätherische Öle und Formamidine als Insektizide/ Akarizide. Welches sind die molekularen Wirkorte?

GABA / G Protein-gekoppelter Rezeptor / Octopamin / Thymol / Tyramin

\section{REFERENCES}

Anthony, J.P., Fyfe, L., Smith, H. (2005) Plant active components - a resource for antiparasitic agents? Trends Parasitol. 21, 462-468

Baxter, G.D., Barker, S.C. (1999) Isolation of a cDNA for an octopamine-like, G-protein coupled receptor from the cattle tick, Boophilus microplus. Insect Biochem. Mol. Biol. 29, 461-467

Beggs, K.T., Hamilton, I.S., Kurshan, P.T., Mustard, J. A., Mercer, A.R. (2005) Characterization of a D2-like dopamine receptor (AmDOP3) in honey bee, Apis mellifera. Insect Biochem. Mol. Biol. 35, 873-882

Bischof, L.J., Enan, E.E. (2004) Cloning, expression and functional analysis of an octopamine receptor from Periplaneta americana. Insect Biochem. Mol. Biol. 34, 511-521

Blenau, W., Baumann, A. (2001) Molecular and pharmacological properties of insect biogenic amine receptors: lessons from Drosophila melanogaster and Apis mellifera. Arch. Insect Biochem. Physiol. 48, 13-38 
Blenau, W., Baumann, A. (2003) Aminergic signal transduction in invertebrates: focus on tyramine and octopamine receptors. Recent Res Dev Neurochem 6, $225-240$

Blenau, W., Thamm, M. (2011) Distribution of serotonin (5-HT) and its receptors in the insect brain with focus on the mushroom bodies: lessons from Drosophila melanogaster and Apis mellifera. Arthropod Struct. 40, 381-394

Blenau, W., Erber, J., Baumann, A. (1998) Characterization of a dopamine D1 receptor from Apis mellifera: cloning, functional expression, pharmacology, and mRNA localization in the brain. J. Neurochem. 70, 15-23

Blenau, W., Balfanz, S., Baumann, A. (2000) Amtyr1: characterization of a gene from honeybee (Apis mellifera) brain encoding a functional tyramine receptor. J. Neurochem. 74, 900-908

Bloomquist, J.R. (1996) Ion channels as targets for insecticides. Annu. Rev. Entomol. 41, 163-190

Brody, T., Cravchik, A. (2000) Drosophila melanogaster $\mathrm{G}$ protein-coupled receptors. J. Cell Biol. 150, F83-F88

Buckingham, S.D., Biggin, P.C., Sattelle, B.M., Brown, L.A., Sattelle, D.B. (2005) Insect GABA receptors: splicing, editing, and targeting by antiparasitics and insecticides. Mol. Pharmacol. 68, 942-951

Calderone, N.W. (2010) Evaluation of Mite-Away-II for fall control of Varroa destructor (Acari: Varroidae) in colonies of the honey bee Apis mellifera (Hymenoptera: Apidae) in the northeastern USA. Exp. Appl. Acarol. 50, 123-132

Calderone, N.W., Spivak, M. (1995) Plant extracts for control of the parasitic mite Varroa jacobsoni (Acari: Varroidae) in colonies of the western honey bee (Hymenoptera, Apidae). J. Econ. Entomol. 88, 1211-1215

Chappell, J. (1995) Biochemistry and molecular biology of the isoprenoid biosynthetic pathway in plants. Annu. Rev. Plant Physiol. Plant Mol. Biol. 46, 521-547

Chen, A., Holmes, S.P., Pietrantonio, P.V. (2004) Molecular cloning and functional expression of a serotonin receptor from the Southern cattle tick, Boophilus microplus (Acari: Ixodidae). Insect. Mol. Biol. 13, 45-54

Chen, A.C., He, H., Davey, R.B. (2007) Mutations in a putative octopamine receptor gene in amitrazresistant cattle ticks. Vet. Parasitol. 148, 379383

Cooley, L., Kelley, R., Spradling, A. (1988) Insertional mutagenesis of the Drosophila genome with single P elements. Science 239, 1121-1128

Downer, R.G.H., Gole, J.W.D., Orr, G.L. (1985) Interaction of formamidines with octopamine-, dopamine-, and 5hydroxytryptamine-sensitive adenylate cyclase in the nerve cord of Periplaneta americana. Pestic. Sci. 16, $472-478$
Dudai, Y., Buxbaum, J., Corfas, G., Ofarim, M. (1987) Formamidines interact with Drosophila receptors, alter the flies' behavior and reduce their learning ability. J. Comp. Physiol. A 161, 739-746

Elzen, P.J., Baxter, J.R., Spivak, M., Wilson, W.T. (2000) Control of Varroa jacobsoni Oud. resistant to fluvalinate and amitraz using coumaphos. Apidologie 31, 437-441

Enan, E. (2001) Insecticidal activity of essential oils: octopaminergic sites of action. Comp. Biochem. Physiol. C Toxicol. Pharmacol. 130, 325-337

Enan, E.E. (2005a) Molecular response of Drosophila melanogaster tyramine receptor cascade to plant essential oils. Insect Biochem. Mol. Biol. 35, 309-321

Enan, E.E. (2005b) Molecular and pharmacological analysis of an octopamine receptor from American cockroach and fruit fly in response to plant essential oils. Arch. Insect Biochem. Physiol. 59, 161-171

Evans, P.D., Gee, J.D. (1980) Action of formamidine pesticides on octopamine receptors. Nature 287, 60-62

Evans, P.D., Maqueira, B. (2005) Insect octopamine receptors: a new classification scheme based on studies of cloned Drosophila G-protein coupled receptors. Invert. Neurosci. 5, 111-118

Floris, I., Cabras, P., Garau, V.L., Minelli, E.V., Satta, A., Troullier, J. (2001) Persistence and effectiveness of pyrethroids in plastic strips against Varroa jacobsoni (Acari: Varroidae) and mite resistance in a Mediterranean area. J. Econ. Entomol. 94, 806-810

Floris, I., Satta, A., Cabras, P., Garau, V.L., Angioni, A. (2004) Comparison between two thymol formulations in the control of Varroa destructor: effectiveness, persistence, and residues. J. Econ. Entomol. 97, 187-191

Genersch, E., Aubert, M. (2010) Emerging and re-emerging viruses of the honey bee (Apis mellifera L.). Vet. Res. 41, 54

Ghasemi, V., Moharramipour, S., Tahmasbi, G. (2011) Biological activity of some plant essential oils against Varroa destructor (Acari: Varroidae), an ectoparasitic mite of Apis mellifera (Hymenoptera: Apidae). Exp. Appl. Acarol. 55, 147-154

Gole, J.W.D., Orr, G.L., Downer, R.G.H. (1983) Interaction of formamidines with octopamine-sensitive adenylate cyclase receptor in the nerve cord of Periplaneta americana L. Life Sci. 32, 2939-2947

Grohmann, L., Blenau, W., Erber, J., Ebert, P.R., Strünker, T., Baumann, A. (2003) Molecular and functional characterization of an octopamine receptor from honeybee (Apis mellifera) brain. J. Neurochem. 86, 725-735

Grundy, D.L., Still, C.C. (1985) Inhibition of acetylcholinesterases by pulegone-1,2-epoxide. Pestic. Biochem. Physiol. 23, 383-388

Guzman-Novoa, E., Eccles, L., Calvete, Y., McGowan, J., Kelly, P.G., Correa, A. (2010) Varroa destructor is the main culprit for the death and reduced populations of 
overwintered honey bee (Apis mellifera) colonies in Ontario, Canada. Apidologie 41, 443-450

Hauser, F., Cazzamali, G., Williamson, M., Blenau, W., Grimmelikhuijzen, C.J.P. (2006) A review of neurohormone GPCRs present in the fruitfly Drosophila melanogaster and the honey bee Apis mellifera. Prog. Neurobiol. 80, 1-19

Hauser, F., Cazzamali, G., Williamson, M., Park, Y., Li, B., Tanaka, Y., Predel, R., Neupert, S., Schachtner, J., Verleyen, P., Grimmelikhuijzen, C.J. (2008) A genome-wide inventory of neurohormone GPCRs in the red flour beetle Tribolium castaneum. Front. Neuroendocrinol. 29, 142165

Hill, C.A., Fox, A.N., Pitts, R.J., Kent, L.B., Tan, P.L., Chrystal, M.A., Cravchik, A., Collins, F.H., Robertson, H.M., Zwiebel, L.J. (2002) G protein-coupled receptors in Anopheles gambiae. Science 298, 176-178

Hirashima, A., Huang, H. (2008) Homology modeling, agonist binding site identification, and docking in octopamine receptor of Periplaneta americana. Comput. Biol. Chem. 32, 185-190

Hiripi, L., Juhos, S., Downer, R.G. (1994) Characterization of tyramine and octopamine receptors in the insect (Locusta migratoria migratorioides) brain. Brain Res. 633, 119-126

Hollingworth, R.M. (1976) Chemistry, biological activity, and uses of formamidine pesticides. Environ. Health Perspect. 14, 57-69

Hollingworth, R.M., Murdock, L.L. (1980) Formamidine pesticides: octopamine-like actions in a firefly. Science 208, 74-76

Holstein, S.A., Hohl, R.J. (2004) Isoprenoids: remarkable diversity of form and function. Lipids 39, 293-309

Hoppe, H. (1990) Vergleichende Untersuchungen zur Biotechnischen Bekämpfung der Varroatose. Dissertation, Justus-Liebig-Universität Giessen

Houghton, P.J., Ren, Y., Howes, M.J. (2006) Acetylcholinesterase inhibitors from plants and fungi. Nat. Prod. Rep. 23, 181-199

Huang, J., Hamasaki, T., Ozoe, F., Ohta, H., Enomoto, K., Kataoka, H., Sawa, Y., Hirota, A., Ozoe, Y. (2007) Identification of critical structural determinants responsible for octopamine binding to the $\alpha$ adrenergic-like Bombyx mori octopamine receptor. Biochemistry 46, 5896-5903

Humphries, M.A., Mustard, J.A., Hunter, S.J., Mercer, A., Ward, V., Ebert, P.R. (2003) Invertebrate D2 type dopamine receptor exhibits age-based plasticity of expression in the mushroom bodies of the honeybee brain. J. Neurobiol. 55, 315-330

Imdorf, A., Kilchenmann, V., Bogdanov, S., Bachofen, B., Beretta, C. (1995) Toxizität von Thymol, Campher, Menthol und Eucalyptol auf Varroa jacobsoni Oud und Apis mellifera L. im Labortest. Apidologie 26, 27-31
Imdorf, A., Bogdanov, S., Ochoa, R.I., Calderone, N.W. (1999) Use of essential oils for the control of Varroa jacobsoni Oud. in honey bee colonies. Apidologie 30, 209-228

Isman, M.B. (2006) Botanical insecticides, deterrents, and repellents in modern agriculture and an increasingly regulated world. Annu. Rev. Entomol. 51, 45-66

Jonsson, N.N., Hope, M. (2007) Progress in the epidemiology and diagnosis of amitraz resistance in the cattle tick Boophilus microplus. Vet. Parasitol. 146, 193-198

Keane, S., Ryan, M.F. (1999) Purification, characterisation, and inhibition by monoterpenes of acetylcholinesterase from the waxmoth, Galleria mellonella (L.). Insect Biochem. Mol. Biol. 29, 1097-1104

Kostyukovsky, M., Rafaeli, A., Gileadi, C., Demchenko, N., Shaaya, E. (2002) Activation of octopaminergic receptors by essential oil constituents isolated from aromatic plants: possible mode of action against insect pests. Pest Manag. Sci. 58, 11011116

Le Conte, Y., Ellis, M., Ritter, W. (2010) Varroa mites and honey bee health: can Varroa explain part of the colony losses? Apidologie 41, 353-363

Lee, S.E., Lee, B.H., Choi, W.S., Park, B.S., Kim, J.G., Campbell, B.C. (2001) Fumigant toxicity of volatile natural products from Korean spices and medicinal plants towards the rice weevil, Sitophilus oryzae (L). Pest. Manag. Sci. 57, 548-553

Lee, S.P., Buber, M.T., Yang, Q., Cerne, R., Cortés, R.Y., Sprous, D.G., Bryant, R.W. (2008) Thymol and related alkyl phenols activate the hTRPA1 channel. Br. J. Pharmacol. 153, 1739-1749

Macpherson, L.J., Hwang, S.W., Miyamoto, T., Dubin, A.E., Patapoutian, A., Story, G.M. (2006) More than cool: promiscuous relationships of menthol and other sensory compounds. Mol. Cell. Neurosci. 32, 335-343

Meyer, J.M., Ejendal, K.F., Watts, V.J., Hill, C.A. (2011) Molecular and pharmacological characterization of two $\mathrm{D}(1)$-like dopamine receptors in the Lyme disease vector, Ixodes scapularis. Insect Biochem. Mol. Biol. 41, 563-571

Milani, N., Lob, M. (1998) Plastic strips containing organophosphorous acaricides to control Varroa jacobsoni. Am. Bee J. 138, 612-615

Mondet, F., Goodwin, M., Mercer, A. (2011) Age-related changes in the behavioural response of honeybees to Apiguard ${ }^{\mathbb{R}}$, a thymol-based treatment used to control the mite Varroa destructor. J. Comp. Physiol. A 197, 1055-1062

Mustard, J.A., Blenau, W., Hamilton, I.S., Ward, V.K., Ebert, P.R., Mercer, A.R. (2003) Analysis of two D1-like dopamine receptors from the honey bee Apis mellifera reveals agonist-independent activation. Mol. Brain Res. 113, 67-77 
Mustard, J.A., Kurshan, P.T., Hamilton, I.S., Blenau, W., Mercer, A.R. (2005) Developmental expression of a tyramine receptor gene in the brain of the honey bee, Apis mellifera. J. Comp. Neurol. 483, 66-75

Mutinelli, F., Rademacher, E. (2003) The use of drugs to control varroosis in honey bee colonies and European legislation: the current situation. Bee World 84, 55-59

Nerio, L.S., Olivero-Verbel, J., Stashenko, E. (2010) Repellent activity of essential oils: a review. Bioresour. Technol. 101, 372-378

Parnas, M., Peters, M., Dadon, D., Lev, S., Vertkin, I., Slutsky, I., Minke, B. (2009) Carvacrol is a novel inhibitor of Drosophila TRPL and mammalian TRPM7 channels. Cell Calcium 45, 300-309

Picollo, M.I., Toloza, A.C., Mougabure, C.G., Zygadlo, J., Zerba, E. (2008) Anticholinesterase and pediculicidal activities of monoterpenoids. Fitoterapia 79, 271-278

Price, D.N., Berry, M.S. (2006) Comparison of effects of octopamine and insecticidal essential oils on activity in the nerve cord, foregut, and dorsal unpaired median neurons of cockroaches. J. Insect Physiol. 52, 309-319

Priestley, C.M., Williamson, E.M., Wafford, K.A., Sattelle, D.B. (2003) Thymol, a constituent of thyme essential oil, is a positive allosteric modulator of human $\mathrm{GABA}_{\mathrm{A}}$ receptors and a homo-oligomeric GABA receptor from Drosophila melanogaster. Br. J. Pharmacol. 140, 1363-1372

Rademacher, E. (1981) Laborversuche mit K-79 im Einsatz gegen Varroa jacobsoni. In: Diagnose und Therapie der Varroatose. Apimondia, Bucharest, pp. 155-167

Rademacher, E. (1990) Die Varroatose der BienenGeschichte, Diagnose, Therapie. Verlag Schelzky und Jeep, Berlin

Rademacher, E., Harz, M. (2006) Oxalic acid for the control of varroosis in honey bee colonies-a review. Apidologie 37, 98-120

Rademacher, E., Imdorf, A. (2004) Legalization of the use of oxalic acid in Varroa control. Bee World 85, 70-72

Rademacher, E., Radtke, J. (2001) Investigations on the use of Thymovar against varroatosis. Apidologie 32, 488-489

Raghu, P., Hardie, R.C. (2009) Regulation of Drosophila TRPC channels by lipid messengers. Cell Calcium 45, 566-573

Roeder, T. (1995) Pharmacology of the octopamine receptor from locust central nervous tissue (OAR3). Br. J. Pharmacol. 114, 210-216

Rosenkranz, P., Aumeier, P., Ziegelmann, B. (2010) Biology and control of Varroa destructor. J. Invertebr. Pathol. 103(Suppl 1), S96-S119

Rotte, C., Krach, C., Balfanz, S., Baumann, A., Walz, B., Blenau, W. (2009) Molecular characterization and localization of the first tyramine receptor of the American cockroach (Periplaneta americana). Neuroscience 162, 1120-1133

Ryan, M.F., Byrne, O. (1988) Plant-insect coevolution and inhibition of acetylcholinesterase. J. Chem. Ecol. 14, 1965-1975

Sammataro, D., Gerson, U., Needham, G. (2000) Parasitic mites of honey bees: life history, implications, and impact. Annu. Rev. Entomol. 45, 519-548

Scheiner, R., Baumann, A., Blenau, W. (2006) Aminergic control and modulation of honeybee behaviour. Curr. Neuropharmacol. 4, 259-276

Schlenstedt, J., Balfanz, S., Baumann, A., Blenau, W.

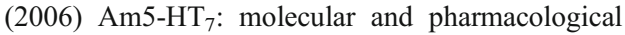
characterization of the first serotonin receptor of the honeybee (Apis mellifera). J. Neurochem. 98, 1985-1996

Siramon, P., Ohtani, Y., Ichiura, H. (2009) Biological performance of Eucalyptus camaldulensis leaf oils from Thailand against the subterranean termite Coptotermes formosanus Shiraki. J. Wood Sci. 55, 41-46

Stone, B.F., Atkinson, P.W., Knowles, C.O. (1974) Formamidine structure and detachment of the cattle tick Boophilus microplus. Pest. Biochem. Physiol. 4, 407-416

Thamm, M., Balfanz, S., Scheiner, R., Baumann, A., Blenau, W. (2010) Characterization of the 5-HT $1 \mathrm{~A}$ receptor of the honeybee (Apis mellifera) and involvement of serotonin in phototactic behavior. Cell. Mol. Life Sci. 67, 2467-2479

Tong, F., Coats, J.R. (2010) Effects of monoterpenoid insecticides on $\left[{ }^{3} \mathrm{H}\right]$-TBOB binding in house fly GABA receptor and ${ }^{36} \mathrm{Cl}^{-}$uptake in American cockroach ventral nerve cord. Pest. Biochem. Physiol. 98, 317-324

Troppmann, B., Balfanz, S., Baumann, A., Blenau, W. (2010) Inverse agonist and neutral antagonist actions of synthetic compounds at an insect $5-\mathrm{HT}_{1}$ receptor. Br. J. Pharmacol. 159, 1450-1462

Vanden Broeck, J., Vulsteke, V., Huybrechts, R., De Loof, A. (1995) Characterization of a cloned locust tyramine receptor cDNA by functional expression in permanently transformed Drosophila S2 cells. J. Neurochem. 64, 2387-2395

Vanengelsdorp, D., Evans, J.D., Saegerman, C., Mullin, C., Haubruge, E., Nguyen, B.K., Frazier, M., Frazier, J., Cox-Foster, D., Chen, Y., Underwood, R., Tarpy, D.R., Pettis, J.S. (2009) Colony collapse disorder: a descriptive study. PLoS One 4, e6481

Venkatachalam, K., Montell, C. (2007) TRP channels. Annu. Rev. Biochem. 76, 387-417

Verlinden, H., Vleugels, R., Marchal, E., Badisco, L., Pflüger, H.J., Blenau, W., Vanden Broeck, J. (2010a) The role of octopamine in locusts and other insects. J. Insect Physiol. 56, 854-867

Verlinden, H., Vleugels, R., Marchal, E., Badisco, L., Tobback, J., Pflüger, H.J., Blenau, W., Vanden, 
B.J. (2010b) The cloning, phylogenetic relationship and distribution pattern of two new putative GPCR-type octopamine receptors in the desert locust (Schistocerca gregaria). J. Insect Physiol. 56, 868-875

Vigan, M. (2010) Essential oils: renewal of interest and toxicity. Eur. J. Dermatol. 20, 685-692

Vogt-Eisele, A.K., Weber, K., Sherkheli, M.A., Vielhaber, G., Panten, J., Gisselmann, G., Hatt, H. (2007) Monoterpenoid agonists of TRPV3. Br. J. Pharmacol. 151, 530-540

Wachendörfer, G., Valder, W.A., Kaiser, E., Maul, V., Wissen, W., Ruttner, F., Harlander, P., Becker, W., Bottin, F. (1981) Erfahrungen mit dem Akarizid K 79 (Chlordimeformhydrochlorid) in Hessen zur
Bekämpfung der Varroatose der Honigbiene. Dtsch. Tierarztl. Wochenschr. 88, 161-168

Waliwitiya, R., Belton, P., Nicholson, R.A., Lowenberger, C.A. (2010) Effects of the essential oil constituent thymol and other neuroactive chemicals on flight motor activity and wing beat frequency in the blowfly Phaenicia sericata. Pest. Manag. Sci. 66, 277-289

Xu, H., Delling, M., Jun, J.C., Clapham, D.E. (2006) Oregano, thyme and clove-derived flavors and skin sensitizers activate specific TRP channels. Nat. Neurosci. 9, 628-635

Zucchi, R., Chiellini, G., Scanlan, T.S., Grandy, D.K. (2006) Trace amine-associated receptors and their ligands. Br. J. Pharmacol. 149, 967-978 